\title{
Eating behavior of schizophrenic patients
}

\section{Comportamento alimentar de pacientes com esquizofrenia}

\author{
Ana Carolina AGUIAR-BLOEMER ${ }^{1}$ (D) 0000-0002-8816-9163

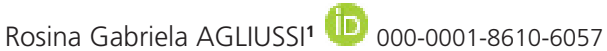 \\ Thiago Maehara Pereira PINHO² (D) 0000-0002-7590-9767 \\ Erikson Felipe FURTADO² (ID) 0000-0001-8006-7077 \\ Rosa Wanda DIEZ-GARCIA ${ }^{1}$ (ID) 0000-0002-7062-974X
}

\section{A B STR ACT}

\section{Objective}

To assess the eating behavior, food practices, nutritional and metabolic profiles of patients with schizophrenia undergoing treatment.

\section{Methods}

Cross-sectional exploratory descriptive qualitative study used a semi-structured questionnaire on the eating behavior, food practices, and perception of changes after the initiation of drug therapy and a quantitative method using anthropometric and body composition measurements, metabolic parameters, and 5-day dietary records to analyze nutrient ingestion of patients with schizophrenia in an outpatient clinic at a tertiary hospital $(n=33)$. The qualitative data were analyzed and coded by three researchers and quantitative data were analyzed using descriptive exploratory statistics.

\footnotetext{
1 Universidade de São Paulo, Faculdade de Medicina de Ribeirão Preto, Departamento Interno de Medicina, Laboratório de Práticas e Comportamento Alimentar - Prática. Av. Bandeirantes, 3900, Monte Alegre, 14049-900, Ribeirão Preto, SP, Brasil. Correspondência para/Correspondence to: RW DIEZ-GARCIA. E-mail: <wanda@fmrp.usp.br>.

2 Universidade de São Paulo, Hospital Universitário de Ribeirão Preto, Departamento de Neurociências e Ciências do Comportamento, Divisão de Psiquiatria. Ribeirão Preto, SP, Brasil.

Article based on the doctoral dissertation of RG AGLIUSSI, intitled "Perfil nutricional, metabólico e alimentar de pacientes portadores de transtornos mentais em tratamento com psicofármacos”. Universidade de São Paulo; 2012.
}

Como citar este artigo/How to cite this article

Aguiar-Bloemer AC, Agliussi RG, Pinho TMP, Furtado EF, Diez-Garcia RW. Eating behavior of schizophrenic patients. Rev Nutr. 2018;31(1):13-24. https://doi.org/10.1590/1678-98652018000100002 


\section{Results}

The results of this study showed that schizophrenic patients presented high prevalence of excess weight (71.0\%), metabolic syndrome (42.0\%), dyslipidemia (62.0\%), changes in appetite $(76.0 \%)$, and increase in energy intake (74.2\%), associated with important irregularities in eating behavior and food practices (such as irregularity of meals, emotional intake, high carbohydrate and fat intake, and low energy expenditure) and lifestyle (changes in social and work routines).

\section{Conclusion}

This eating profile may interact synergistically with psychotropic drugs to contribute to weight gain and metabolic changes in schizophrenia. Nutrition education may prevent and monitor the risk of metabolic and nutrition problems, irrespective of the medications used.

Keywords: Eating. Feeding behavior. Food consuption. Metabolome. Schizophrenia.

\section{RE S U M O}

\section{Objetivo}

Avaliar o comportamento e as práticas alimentares, o perfil nutricional e metabólico de pacientes com esquizofrenia em tratamento ambulatorial de um hospital terciário.

\section{Métodos}

Trata-se de estudo descritivo exploratório transversal com abordagem qualitativa utilizando questionário semi-estruturado sobre comportamentos alimentares, práticas alimentares e percepção de mudanças após o início da terapia medicamentosa e abordagem quantitativa usando medidas antropométricas e de composição corporal, parâmetros metabólicos e registros alimentares por cinco dias para analisar a ingestão de nutrientes em pacientes com esquizofrenia $(n=33)$. Os dados qualitativos foram analisados e codificados por três pesquisadores e os dados quantitativos foram analisados utilizando estatísticas exploratórias descritivas.

\section{Resultados}

Os resultados deste estudo mostraram que os pacientes com esquizofrenia apresentaram uma alta prevalência de excesso de peso $(71,0 \%)$, síndrome metabólica $(42,0 \%)$ e dislipidemia $(62,0 \%)$, com alterações no apetite (76,0\%), consumo excessivo de energia (74,2\%), associado à irregularidades no comportamento alimentar e nas práticas alimentares (como a irregularidade das refeições, o consumo emocional, a ingestão elevada de carboidratos e gorduras e o baixo gasto de energia) e o estilo de vida (mudanças nas rotinas sociais e de trabalho).

\section{Conclusão}

Esse perfil alimentar pode interagir sinergicamente com às drogas psicotrópicas utilizadas o tratamento de esquizofrenia contribuindo com o ganho de peso e alterações metabólicas após o diagnóstico da doença. Nesse sentido, acredita-se que a educação nutricional pode prevenir e monitorar o risco de problema metabólico e nutricional, independentemente dos medicamentos utilizados.

Palavras-chave: Ingestão de alimentos. Comportamento alimentar. Consumo de alimentos. Metaboloma. Esquizofrenia.

\section{INTRODUCTION}

Patients with schizophrenia undergoing treatment may experience weight gain [1,2], changes in the basal metabolic rate [3], lipid metabolism [4], appetite hormones (ghrelin and leptin) [5,6], and insulin resistance [7].
The weight gain mechanism in psychiatric patients is still unclear, however, it is known that medications may cause metabolic alterations in the satiety center and in the food reward system [8], in addition to side effects that lead to lower energy expenditure such as sedation [2]. In addition, patients with schizophrenia have a lower 
basal energy expenditure [9] and may refrain from work, household chores, and physical activities regardless of the medication used, which can cause weight gain [10].

The medications used in the treatment of schizophrenia are classified into two groups: typical antipsychotics (comprising 15 drugs) and atypical antipsychotics (clozapine, olanzapine, risperidone, quetiapine, aripiprazole, and ziprasiadone), which cause less negative symptoms and fewer extrapyramidal symptoms. In addition to antipsychotics, antidepressants (fluoxetine, paroxetine, sertraline, duloxetine, bupropion, and mirtazapine) and mood stabilizers (lithium, valproic acid, carbamazepine, lamotrigine) are commonly prescribed to schizophrenic patients to treat comorbidity disorders, side effects, and potentialize atypical medication [11].

This high incidence increases the risk of developing metabolic disorders and explains the high prevalence of mortality due to obesity-related problems in this group [12]. The prevalence of metabolic syndromes in medicated patients with schizophrenia was $35.3 \%$, which is significantly higher than unmedicated patients with schizophrenia (prevalence: 5.2\%-15.6\%; $p<0.001)$ or first-episode patients (prevalence: $6.1-14.5 \% ; p<0.001)$.

Although certain medications may contribute to weight gain, several other priorities are important to establish/several other aspects are relevant concerning the drug therapy of patients, making it difficult to consider the metabolic aspects triggered by the drug. On the other hand, weight gain could decrease adherence to treatment and quality of life [13].

Additionally, eating behavior and food practices can be directly related to weight gain, such as emotional intake, sweet craving, dietary intake, energy expenditure, and lifestyle, irrespective of the medications used. Considering this, the aim of this study was to assess eating behavior, food practices, the nutritional and metabolic profile of patients diagnosed with schizophrenia undergoing treatment in a tertiary hospital.

\section{METHODS}

This is a cross-sectional exploratory descriptive study using quantitative and qualitative data in accordance with the methods of Draper \& Swift [14]. For one year, all nonpregnant patients over the age of 18 years who attended the outpatient clinic and were able to provide information, had no addiction to alcohol or illicit drugs, and did not have diabetes Mellitus were assessed. The sample consisted of all patients who had been attending the clinic for 11 months, met the inclusion criteria, and agreed to participate in the research. In the outpatient clinic, the patients were diagnosed by Diagnostic and Statistical Manual of Mental Disorders IV (DSM-IV) criteria. The project was approved by the Research Ethics Committee and all participants (protocol n 3569/2010) included in the study signed an informed consent form. A semi-structured questionnaire and dietary records were used to assess eating behavior and food practices. The semi-structured questionnaire contained information on appetite, peak hunger times, food preferences, sweet craving $[15,16]$, and the influence of drug therapy on lifestyle. In addition, the dietary record was applied for five days (two 24-hour dietary recalls and threeday food record) to analyze the regularity and frequency of meals, type of food intake, and adequacy of macro- and micronutrient intake. The software Dietpro 5i® (Dietpro, Viçosa, Minas Gerais, Brazil) was used to calculate the composition of the diet and the criteria of Dietary Reference Intakes (DRI) to verify adequacy of nutrients.

Weight, height, Body Mass Index (BMI), and abdominal circumference were measured to assess nutritional status of patients. Body composition was evaluated by electrical bioimpedance measurement (Biodynamics 450, four-electrode bioimpedance analyzer, which consists of the passage of an 
electric current $(800 \mu \mathrm{A}, 50 \mathrm{kHz})$ to measure the conductivity of body tissues based on the values of resistance, reactance, and phase angle). In addition, the Harris-Benedict equation, which uses gender, weight, height, age, and activity factor was used to assess patients' individual Total Energy Expenditure (TEE). For patients with inadequate weight (below $25 \%$ or above $95 \%$ the ideal weight), the adjusted weight was used as weight factor to calculate TEE. To assess the metabolic profile, total cholesterol and fractions, glycaemia, and basal insulin were analyzed. The metabolic syndrome was assessed considering the criteria adopted by National Cholesterol Education Programme/Adult Treatment Panel III (NCEP/ATP III) [17].

The semi-structured questionnaire was analyzed and coded by three researchers. The characterization of the sample, data on nutritional and metabolic profiles, and data on dietary intake were analyzed using descriptive exploratory statistics, such as median, minimum and maximum values, mean, standard deviation, and percentage using the $S A S^{\circledR} 9$ software (Statistical Analysis System, Cary, North of Carolina, USA).

\section{RES U L T S}

The sample consisted of 33 schizophrenic patients (24 men and 7 women), with mean ages of $41.7 \pm 12.6$ years. Two patients were excluded due to insufficient data. Most patients were single $(77.4 \%)$, unemployed $(77.4 \%)$, and only $35.0 \%$ practiced physical activity. Fortyeight percent of patients had more than eight years of schooling.

Atypical medications (65\%) were administered to most patients, followed by patients who were administered a combination of typical and atypical drugs (17\%) and, with the same percentage frequency, patients who were administered typical and atypical antipsychotic medications combined with mood stabilizers (9\%), and $19 \%$ of patients were administered antidepressants.

\section{Eating behavior and food practices}

Chart 1 shows the main results of the semi-structured questionnaire on food behavior and food practices. The patients associated the use of medication with changes in their dietary

Chart 1. Eating behaviour and food practice characteristics found in patients with schizophrenia in outpatient clinic treatment.

\begin{tabular}{|c|c|}
\hline \multirow{6}{*}{ Eating behaviour } & Some atypical dietary practices were reported (consumption of large amounts of specific food). \\
\hline & Aspects of emotional food intake. \\
\hline & $\begin{array}{l}75.9 \% \text { of the patients experienced changes in appetite while } 62.9 \% \text { reported increased } \\
\text { appetite. }\end{array}$ \\
\hline & Patients started eating more quickly. \\
\hline & $16.1 \%$ reported sweet craving. \\
\hline & $33.3 \%$ prefer savory foods and $14.8 \%$ prefer sweet foods. \\
\hline \multirow{3}{*}{ Food practices } & $\begin{array}{l}\text { Increased consumption of foods with high energy density, simple carbohydrates, and fat (e.g.: } \\
\text { cookies, pizza, sweet chocolates, and soft drinks). }\end{array}$ \\
\hline & $61.2 \%$ consumed $>15.0 \%$ beyond their energy requirement. \\
\hline & $67.7 \%$ presented absence of dietary patterns or irregular meal frequency. \\
\hline \multirow{4}{*}{$\begin{array}{l}\text { Characteristics during psychiatric } \\
\text { decompensation }\end{array}$} & Increased food intake (amount, frequency, and seeking specific foods). \\
\hline & $\begin{array}{l}\text { Low food intake related to decreased appetite, sensory changes in olfaction and taste, and } \\
\text { delusions of poisoned food. }\end{array}$ \\
\hline & Changes in eating times. \\
\hline & Increased water intake. \\
\hline
\end{tabular}


habits, such as eating food more quickly and increasing intake of foods with high energy density, simple carbohydrates, and fat, such as cookies, pizza, sweet chocolate, and soft drinks. Some patients associated somnolence caused by the medication with changes in dietary routine such as irregular meal frequency and lower food intake.

Emotional aspects were mentioned in several reports such as "I feel happy when I eat", "When I am calmer and more relaxed, I end up eating more", and "If I don't eat, I get in a bad mood". The attempt to restrict dietary intake due to the concern about weight gain was observed in reports such as "I try to restrain myself to prevent weight gain", "I tried to cut down my diet", "I tried to go on a diet, but failed", and "I tried to change the situation alone, but I failed".

The absence of regular dietary patterns or irregular meal frequency (such as no eating routine, eating at different times of the day, and eating different types of food at the same time on different days) was found in $67.7 \%$ of the dietary records of the patients assessed.

Some patients (16.1\%) answered positively when asked about experiencing sweet craving. However, patients reported enjoying sweet foods. The most common sweets reported by the patients were chocolate, gelatin desserts, and peanut candies.

Besides dietary characteristics, some unusual eating behaviors for the local population were observed, such as eating large amounts of popcorn daily, eating several fried pastries or a whole packet of cookies at once, drinking more than two liters of soft drinks, and eating only powdered chocolate, among other examples.

As for their dietary preferences, most patients did not report a preference for any specific type of food (51.8\%), followed by a preference for savory (33.3\%) and sweet foods (14.8\%).

Among the patients who reported increasing their dietary intake during psychiatric decompensation, some increased the quantity of food intake, others sought different foods (especially candies), while others increased the frequency of food intake. Other important reports were changes in eating times and increased water intake. These changes were mainly expressed by statements such as "I didn't use to overeat", "I began snacking more", "I began feeling hungrier", "I felt weakness in the stomach", "I seemed to be ravenous", and "Nothing filled me up" (Chart 1). Low food intake was related to decreased appetite, sensory changes in olfaction and taste, and delusions of poisoned food.

\section{Perception of changes after the initiation of drug therapy}

The association between drug therapy initiation and body weight gain was mentioned by $66.6 \%$ of the patients, some of whom related this fact with increased food intake, while others related it only after the initiation of drug therapy. When detailing the weight gain process, the answers varied widely; some said it was sudden, while others described it as gradual. Reported weight gain ranged from 4 to $14 \mathrm{~kg}$ in comparison with initial weight. The statements that portray this change in weight were "I used to be slim, like a broomstick, I had a model body", and "before the disease, I didn't like eating and I was very thin", among others.

With regard to the perception of the influence of drug therapy on dietary aspects, $75.9 \%$ of the patients mentioned changes in appetite, most of whom (62.9\%) reported increased appetite. Olanzapine and clozapine were the drugs most associated with increased appetite.

A significant number of patients reported (84\%) that treatment initiation changed their routines. The main changes in lifestyle of patients were job and school quitting, interruption of 
household chores, administration of sleeping aids, lack of sexual interest, and social isolation (Chart 2).

\section{Food intake}

The mean and standard deviation of the energy intake in the food diaries (recalls and food records applied for five days) of the patients was $2,263 \pm 456 \mathrm{kcal}$ daily. According to the criteria by Harris Benedict, the mean daily energy requirement of the sample is 1,857 calories. When the energy requirement and energy intake of each participant were compared, it was found that $74.1 \%$ of patients had inadequate energy intake, $61.2 \%$ of the total sample consumed more than $15.0 \%$ above their daily energy requirement, and $13.0 \%$ of patients consumed less than $65.0 \%$ of their energy requirement. The means and adjustments according to DRI values of macro and micronutrients are shown in Table 2. The patients also had mean intake of $22.4 \mathrm{~g}$ of saturated fatty acids, $28.8 \mathrm{~g}$ of monounsaturated fatty acids, and $25.1 \mathrm{~g}$ of polyunsaturated fatty acids.

\section{Nutritional and metabolic profile}

The mean and standard deviation of the $\mathrm{BMl}$ in the sample were $28.2 \pm 5.4 \mathrm{~kg} / \mathrm{m}^{2}$ (median of $29.4 \mathrm{~kg} / \mathrm{m}^{2}$, minimum 16.2 and maximum $\left.37.6 \mathrm{~kg} / \mathrm{m}^{2}\right)$ and $70.9 \%$ of the patients were overweight (BMI $>24.9 \mathrm{~kg} / \mathrm{m}^{2}$ [18] whereas $48.3 \%$ were obese $\left(\mathrm{BMI} \geq 30 \mathrm{~kg} / \mathrm{m}^{2}\right)$. The mean abdominal circumference was $95.9 \pm 13.9 \mathrm{~cm}$ for men and $108.7 \pm 4.3 \mathrm{~cm}$ for women, that is, the abdominal circumference measurement of $80.6 \%$ of the population studied was above the values considered adequate (men $\geq 90 \mathrm{~cm}$ and women $\geq 80 \mathrm{~cm}$ [19].

The assessment of body composition by electrical bioimpedance showed that $75.00 \%$ of the men $(27.7 \pm 6.31 \%)$ and $100.00 \%$ of the women $(41.4 \pm 3.10 \%)$ had excess body fat according to the parameters by Pollock \& Wilmore [20].

As for the biochemical parameters, the cholesterol levels of $62.0 \%$ of the patients were above the levels recommended and Low Density Lipoprotein (LDL), Very Low Density Lipoprotein (VLDL), and triglyceride levels of $80.6 \%$ were above the recommended levels (Table 1 and Chart 2).

Given the criteria adopted by National Cholesterol Education Programme Adult Treatment Panel III, $41.9 \%$ of the sample presented metabolic syndrome. Moreover, according to the Homeostasis Model Assessment (HOMA) and Quick Insulin Assay reference values, 25.8\% of the patients presented insulin resistance [17].

\section{DISCUSSION}

The results of this study showed that the patients had several dietary inadequacies

Chart 2. Lifestyle, metabolic profile and weight change.

\begin{tabular}{ll}
\hline Lifestyle & $77.4 \%$ did not work. \\
& $35.0 \%$ did physical activity. \\
\hline & $62.0 \%$ had cholesterol above recommendation. \\
& $80.6 \%$ had LDL, VLDL, and TG above recommendation. \\
Metabolic profile & $41.9 \%$ had metabolic syndrome. \\
& $25.8 \%$ had insulin resistance. \\
\hline \multirow{2}{*}{ Changes in weight } & $66.6 \%$ had ponderal gain. \\
\hline
\end{tabular}

Note: LDL: Low Density Lipoprotein; VLDL: Very Low Density Lipoprotein. TG: Triglycerides. 
Table 1. Anthropometric measures, body composition, and metabolic characteristics of patients with schizophrenia undergoing outpatient clinic treatment.

\begin{tabular}{|c|c|c|c|c|c|}
\hline Characteristics & Mean & \pm & SD & Median & $(\min -\max )$ \\
\hline \multicolumn{6}{|l|}{ Anthropometric } \\
\hline Weight (kg) & 79.60 & \pm & 14.90 & 76.00 & $(52.2-109.9)$ \\
\hline BMI $\left(\mathrm{kg} / \mathrm{m}^{2}\right)$ & 28.20 & \pm & 5.40 & 29.40 & $(16.2-37.6)$ \\
\hline Abdominal circumference $(\mathrm{cm})$ & 98.70 & \pm & 13.40 & 101.70 & $(64.0-116.7)$ \\
\hline \multicolumn{6}{|l|}{ Body composition } \\
\hline Body fat (\%) & 30.50 & \pm & 7.90 & 29.10 & $(12.6-43.8)$ \\
\hline Lean mass (kg) & 54.80 & \pm & 9.50 & 53.10 & $(35.9-75.4)$ \\
\hline \multicolumn{6}{|l|}{ Metabolic } \\
\hline Total cholesterol (mg/dL) & 211.60 & \pm & 46.60 & 203.50 & $(128.0-306.0)$ \\
\hline $\mathrm{HDL}(\mathrm{mg} / \mathrm{dL})$ & 41.30 & \pm & 10.60 & 40.50 & $(24.0-69.0)$ \\
\hline LDL (mg/dL) & 131.10 & \pm & 38.10 & 126.50 & $(54.0-195.0)$ \\
\hline VLDL (mg/dL) & 34.70 & \pm & 15.90 & 32.00 & $(9.0-70.0)$ \\
\hline Triglycerides (mg/dL) & 224.40 & \pm & 171.40 & 168.50 & $(48.0-713.0)$ \\
\hline Glycemia (mg/dL) & 89.90 & \pm & 9.40 & 88.00 & (71.0-109.0) \\
\hline Basal insulin $(\mu \mathrm{IU} / \mathrm{mL})$ & 8.80 & \pm & 7.80 & 6.00 & $(2.0-33.0)$ \\
\hline HOMA & 2.93 & \pm & 2.19 & 1.29 & $(0.40-8.71)$ \\
\hline QUICKI & 0.34 & \pm & 0.04 & 0.36 & $(0.28-0.45)$ \\
\hline
\end{tabular}

Note: BMI: Body Mass Index; HDL: High Density Lipoprotein; LDL: Low Density Lipoprotein; VLDL: Very Low Density Lipoprotein; SD: Standard Deviation; HOMA: Homeostasis Model Assessment; QUICK: Quick Insulin Assay.

Table 2. Mean intake of macro and micronutrients assessed by five-day dietary records and adequacies according to the DRI.

\begin{tabular}{|c|c|c|c|c|}
\hline \multirow[b]{2}{*}{ Nutrient (mean) } & \multirow[b]{2}{*}{ Overall mean } & \multicolumn{3}{|c|}{ Percentage of patients with the following adequacies } \\
\hline & & $<\operatorname{EAR}(\%)$ & $\begin{array}{c}\text { EAR-RDA (\%) or acceptable } \\
\text { variation (AMDR) }\end{array}$ & $\begin{array}{c}\text { RDA-UL (\%) above the } \\
\text { acceptable variation (AMDR) }\end{array}$ \\
\hline Proteins (g) & 74.5 & 0.0 & 16.7 & 83.3 \\
\hline Carbohydrates (g) & 281.3 & 0.0 & 3.3 & 96.7 \\
\hline Lipids (g) & 93.6 & 0.0 & 6.4 & 93.6 \\
\hline Fiber (g) & 17.2 & 96.7 & 3.2 & 0.0 \\
\hline Calcium (mg) & 488.6 & 90.0 & 6.7 & 3.3 \\
\hline Iron (mg) & 13.4 & 6.7 & 80.0 & 13.3 \\
\hline Phosphorous (mg) & 924.5 & 13.3 & 3.3 & 83.3 \\
\hline Vitamin C (mg) & 107.0 & 53.3 & 13.3 & 33.3 \\
\hline
\end{tabular}

Note: DRI: Dietary Reference Intakes; EAR: Estimated Average Requirement; RDA: Recommended Dietary Allowance; UL: Tolerable Upper Intake Level. AMDR: Acceptable Macronutrient Distribution Range.

promoted by the lack of regular daily activities. It was found that many eating behaviors and food practices can contribute to weight gain. Emotion related to food intake was one of these aspects. In the healthy population, emotions can stimulate food intake beyond energy requirement, and therefore promote weight gain $[21,22]$. In this study, we observed frequent reports related to emotional intake that can contribute to weight gain.

Studies showed that during the acute phase of illness, patients present a high level 
of stress [23] and stress is associated with the increased desire for palatable food, especially sweet food [16]. In this study, schizophrenic patients increased sweet food intake and increased the frequency of food intake during psychiatric decompensation. Only $16 \%$ of patients presented sweet craving, showing episodes of high and uncontrollable sweet food intake. However, a higher intake of carbohydrates than usual was reported.

The unhealthy lifestyle of schizophrenic patients is frequently reported in the literature [24]. Patients with schizophrenia are more likely to be heavy tobacco users [25] and present insufficient physical activity $[26,27]$. Job quitting, interruption of household chores, administration of sleeping aids, and lack of sexual interest were found in the semi-structured questionnaire, which is probably related to the lower energy expenditure and more time available to eat at home, contributing to increased food intake and weight gain [28-30].

Concerning the food practices analyzed, the dietary records showed that daily energy intake of $61.2 \%$ of the patients was above the requirements, and $96.7 \%$ and $93.6 \%$ of the patients consumed more than the Dietary Reference Intakes recommendation of carbohydrate and lipids, respectively. Those values, associated with underreporting, common in dietary records, might imply more excess energy intake [31]. In addition, $96.7 \%$ and $90.0 \%$ of the patients presented fiber and calcium intake below the levels recommended, respectively, indirectly suggesting low consumption of dairy products and fresh foods, which could reflect the low quality of their diets. In a systematic review of the dietary pattern of schizophrenic patients, Dipasquale et al. showed that most studies also reported low-fiber diets, low fruit intake, and high intake of saturated fat [32]. A cross-sectional study of the dietary pattern in schizophrenia did not find a difference in daily energy intake between the schizophrenic group and group control, but the schizophrenic group consumed a significantly higher quantity of fat and sugar [33]. Studies highlight the impact of the quality of the diet on health, i.e. the implications of consuming ultra-processed food and benefits of fresh food $[34,35]$. At the same time, the high intake of saturated fat ( $22.4 \mathrm{~g}$ per day) and the increased appetite after treatment initiation were associated with the reports of emotional aspects related to consumption. The association of high-fat foods with 'comfort food' is also found in healthy individuals [36].

The known effects of the medications used to treat schizophrenia and the different factors related to the disorder, such as changes in lifestyle, eating behavior, and food practices, may synergistically interact and contribute to weight gain and metabolic changes.

The nutritional, metabolic, and dietary profile of patients with schizophrenia undergoing treatment differed from those of the general Brazilian population. The prevalence of obesity among schizophrenics in this study (48.3\%) was 2.6-fold greater than in the Brazilian population (17.9\%) [37]. Kohlmann et al. also found a higher prevalence among patients with mental disorders (45.0\%) in comparison with the general population in the United States (30.5\%) [21].

Interestingly, the prevalence of obesity in this study was higher than in another study on schizophrenics in Brazil in 2009 (25.6\% obesity), which showed that, similar to the Brazilian population, the incidence of obesity among patients with schizophrenia has been increasing over the years [38]. This difference might be related to the different medications associated with weight gain and increased consumption of ultra-processed food in this population $[34,39,40]$.

Patients treated with atypical antipsychotics may gain $20 \%$ of their initial weight [41], which may favor the onset of complications such as diabetes, dyslipidemia, and hypertension [42]. In the present study, weight change reported by the patients was significant (between 4 
and 14kg). Atypical antipsychotics (used by $91 \%$ of the patients in this study) may be related to weight gain due to their effect on the neurotransmitter system, particularly the serotonergic and histaminergic systems. This class of drugs may block the serotoninergic receptor 5-hydroxytryptamine $2 \mathrm{C}$ (5-HT2C), which plays a role in regulating appetite, which may, thus, increase energy intake. It may also block the histamine $\mathrm{H} 1$ receptor, which may deactivate the satiety center $[43,44]$.

Among the medications classified as atypical, olanzapine and clozapine may cause metabolic abnormalities [45], as well as influence weight gain $[12,41,44,46,47]$. In this study, we found that medication did not influence weight gain of patients throughout treatment. However, most patients were administered olanzapine (46\%), followed by those who were administered clozapine (23\%). This might explain the increased prevalence of obesity found in this study in comparison with other studies conducted in Brazil $[38,48]$. The results of this study suggest that many factors related to the eating behavior and food practices can act synergistically, enhancing weight gain by dietary changes associated with disease and routine change.

Overweight (BMI $\left.>24.9 \mathrm{~kg} / \mathrm{m}^{2}\right)$ was similar to the results of other studies on patients with mental disorders, including those diagnosed with schizophrenia $[38,49,50]$, which confirms that the drugs are a risk factor for overweight and obesity. Abdominal obesity was found in $61.1 \%$ of the patients, which was similar to the results found in other studies on patients with mental disorders that reported a prevalence of abdominal obesity ranging from 41.0 to $61.0 \%$ [51-54].

The high prevalence of abdominal obesity, low High Density Lipoprotein (HDL) levels, and high hypertriglyceridemia rate result in the common occurrence of metabolic syndrome in the group studied (41.9\% of the patients), which was higher than in other studies conducted with patients with the same psychiatric disorder [51-55] and it was higher than in the one found in the healthy Brazilian population (29.8\%) [56].

Similarly to the present research, other studies showed changes in dietary aspects in persons with schizophrenia such as irregular meals, higher consumption of fast meals [57], carbohydrates [58], food rich in fat and saturated fat [58], and low intake of fibers [30], fruit, and vegetables $[59,60]$.

In Spain, Simonelli-Munoz et al. [61] showed that weight gain in patients with schizophrenia is impacted by dietary habits and that, hence, treatment with psychotropic drugs is not the key factor for obesity among those patients. On the same subject, Amani [62] compared the dietary pattern of schizophrenic patients with healthy controls and concluded that the group with schizophrenia consumed greater amounts of fat and sugar-sweetened drinks.

Although the information obtained through the reports, interviews, and records is susceptible to different types of influence, which may compromise the quality and accuracy of information, the qualitative data collected was ensured due to the diversification of methods and analysis of results by cross-referencing the instruments.

The sample size in this study was limited to the number of patients, who met the inclusion criteria, at the outpatient clinic during the period of the study and their conditions for participating in the research, which suggests the need to investigate these characteristics in other locations to consolidate the information and characterization obtained in this study.

\section{CONCLUSION}

This study showed that there are many aspects of eating behaviors and food practices that can promote weight gain, in addition to the effects of drugs on the metabolic profile. Patients with schizophrenia undergoing outpatient clinic 
treatment presented a high prevalence of overweight and body fat, and weight gain was associated with the diagnosis and treatment of the disease and important metabolic changes. These conditions reveal the need for dietary and nutritional care after treatment initiation and aspects related to eating behavior, food practices and lifestyle should be monitored, which must be established early on to reduce nutritional and metabolic disorders associated with the use of medications.

\section{A C KNOWLEDGMENTS}

We would like to thank all patients who participated in the study.

\section{ONTRIBUTRS}

AC AGUIAR-BLOEMER contributed to development of the study, interpretation of the results, drafting of the manuscript, and submission process. TMP PINHO contributed to the interpretation of the statistical results and drafting of the manuscript. RG ALIUSSI contributed to the implementation, data collection, and development of the study. EF FURTADO contributed to the design and implementation of the data collection. RW DIEZ-GARCIA contributed to the design and implementation of the study, interpretation of the results, drafting of the manuscript, and submission process. All authors read, revised, and approved the final version of the manuscript.

\section{REFERE N CES}

1. Bushe CJ, Slooff CJ, Haddad PM, Karagianis JL. Weight change by baseline BMI from three-year observational data: Findings from the Worldwide Schizophrenia Outpatient Health Outcomes Database. J Psychopharmacol. 2013;27(4):358-65.

2. Young SL, Taylor M, Lawrie SM. First do no harm: A systematic review of the prevalence and management of antipsychotic adverse effects. J Psychopharmacol. 2015;29(4):353-62.

3. Ramacciotti $C E$, Paoli RA, Catena M, Ciapparelli A, Dell'Osso L, Schulte $F$, et al. Schizophrenia and binge-eating disorders. J Clin Psychiatry. 2004;65(7):1016-7.
4. Smith RC, Lindenmayer J-P, Hu Q, Kelly E, Viviano TF, Cornwell J, et al. Effects of olanzapine and risperidone on lipid metabolism in chronic schizophrenic patients with long-term antipsychotic treatment: A randomized five month study. Schizophr Res. 2010;120(1-3):204-9.

5. Kim B-J, Sohn J-W, Park C-S, Hahn G-H, Koo J, Noh Y-D, et al. Body weight and plasma levels of ghrelin and leptin during treatment with olanzapine. J Korean Med Sci. 2008;23(4):68590.

6. Chen VC-H, Wang T-N, Lu M-L, Chou J-Y, Ju $\mathrm{P}-\mathrm{C}, \mathrm{Wu} \mathrm{J}-\mathrm{Y}$, et al. Weight gain and ghrelin level after olanzapine monotherapy. Prog NeuroPsychopharmacol Biol Psychiatry. 2011;35(2):6325.

7. Goncalves P, Araujo JR, Martel F. Antipsychoticsinduced metabolic alterations: Focus on adipose tissue and molecular mechanisms. Eur Neuropsychopharmacol. 2015;25(1):1-16.

8. Elman I, Borsook D, Lukas SE. Food intake and reward mechanisms in patients with schizophrenia: Implications for metabolic disturbances and treatment with second-generation antipsychotic agents. Neuropsychopharmacology. 2006;31(10):2091-120.

9. Nilsson BM, Forslund AH, Olsson RM, Hambraeus $L$, Wiesel FA. Differences in resting energy expenditure and body composition between patients with schizophrenia and healthy controls. Acta Psychiatr Scand. 2006;114(1):27-35.

10. Araujo FS, Petribu K, Bastos O. Depression in schizophrenia. Rev Bras Psiquiatr. 2002;24(2):86-93.

11. Miyamoto S, Duncan GE, Marx CE, Lieberman JA. Treatments for schizophrenia: A critical review of pharmacology and mechanisms of action of antipsychotic drugs. Mol Psychiatry. 2005;10(1):79-104.

12. Allison DB, Mentore $J L$, Heo $M$, Chandler LP, Cappelleri JC, Infante MC, et al. Antipsychoticinduced weight gain: A comprehensive research synthesis. Am J Psychiatry. 1999;156(11):168696.

13. Wirshing DA. Schizophrenia and obesity: Impact of antipsychotic medications. J Clin Psychiatry. 2004;65 Suppl 18:13-26.

14. Draper A, Swift JA. Qualitative research in nutrition and dietetics: Data collection issues. J Human Nutr Diet. 2011;24(1):3-12.

15. Weingarten HP, Elston D. Food cravings in a college population. Appetite. 1991;17(3):167-75.

16. Macedo DM, Diez-Garcia RW. Sweet craving and ghrelin and leptin levels in women during stress. Appetite. 2014;80:264-70. 
17. Cleeman JI, Grundy SM, Becker D, Clark LT, Cooper RS, Denke MA, et al. Executive summary of the Third Report of the National Cholesterol Education Program (NCEP) expert panel on detection, evaluation, and treatment of high blood cholesterol in adults (Adult Treatment Panel III). Jama. 2001;285(19):2486-97.

18. World Health Organization. Defining the problem of overweight and obesity. In: World Health Organization. Obesity: Preventing and managing the global epidemic: Report of a WHO Consultation. Geneva: WHO; 2000. p.241-3. WHO Technical Report Series, 894.

19. International Diabetes Federation. Clinical Guidelines Task force: Global guideline for Type 2 diabetes. Brussels: International Diabetes Federation; 2005.

20. Pollock WL, Wilmore JH. Exercícios na saúde e na doença: avaliação e prescrição para prevenção e reabilitação. 2a ed. Rio de Janeiro: MEDSI; 1993.

21. Kohlmann S, Rief W, Westermann S. Emotion regulation, overeating and obesity. J Psychosom Res. 2012;72(6):489.

22. Kishi T, Elmquist JK. Body weight is regulated by the brain: A link between feeding and emotion. Mol Psychiatry. 2005;10(2):132-46.

23. Myin-Germeys I, van Os J. Stress-reactivity in psychosis: Evidence for an affective pathway to psychosis. Clin Psychol Rev. 2007;27(4):409-24.

24. Cerimele JM, Katon WJ. Associations between health risk behaviors and symptoms of schizophrenia and bipolar disorder: A systematic review. Gen Hosp Psychiatry. 2013;35(1):16-22.

25. Ziedonis D, Hitsman B, Beckham J, Zvolensky M, Adler L, Audrain-McGovern J, et al. Tobacco use and cessation in psychiatric disorders: National Institute of Mental Health report. Nicotine Tob Res. 2008;10(12):1691-715.

26. Vancampfort D, Probst M, Scheewe T, De Herdt A, Sweers K, Knapen J, et al. Relationships between physical fitness, physical activity, smoking and metabolic and mental health parameters in people with schizophrenia. Psychiatry Res. 2013;207(12):25-32

27. Kristiansen CB, Juel A, Hansen MV, Hansen AM, Kilian R, Hjorth P. Promoting physical health in severe mental illness: Patient and staff perspective. Acta Psychiatr Scand. 2015;132(6):470-8.

28. Thorp AA, Owen N, Neuhaus M, Dunstan DW. Sedentary behaviors and subsequent health outcomes in adults a systematic review of longitudinal studies, 1996-2011. Am J Prev Med. 2011;41(2):207-15.

29. Vancampfort D, Probst M, Knapen J, Carraro A, De Hert M. Associations between sedentary behaviour and metabolic parameters in patients with schizophrenia. Psychiatry Res. 2012;200(23):73-8.

30. Brown S, Birtwistle J, Roe L, Thompson C. The unhealthy lifestyle of people with schizophrenia. Psychol Med. 1999;29(3):697-701.

31. Scagliusi FB, Lancha Júnior $A H$. Underreporting of energy intake in dietary assessment methods. Rev Nutr. 2003;16(4):471-81. http://dx.doi.org/10.15 90/S1415-52732003000400010

32. Dipasquale S, Pariante CM, Dazzan P, Aguglia E, McGuire P, Mondelli V. The dietary pattern of patients with schizophrenia: A systematic review. J Psychiatr Res. 2013;47(2):197-207.

33. Ratliff JC, Palmese LB, Reutenauer EL, Liskov E, Grilo CM, Tek C. The effect of dietary and physical activity pattern on metabolic profile in individuals with schizophrenia: A cross-sectional study. Comp Psychiatry. 2012;53(7):1028-33.

34. Monteiro CA, Levy RB, Claro RM, Ribeiro de Castro IR, Cannon G. Increasing consumption of ultra-processed foods and likely impact on human health: Evidence from Brazil. Public Health Nutr. 2011;14(1):5-13.

35. Moubarac JC, Martins APB, Claro RM, Levy RB, Cannon G, Monteiro CA. Consumption of ultra-processed foods and likely impact on human health: Evidence from Canada. Public Health Nutr. 2013;16(12):2240-8.

36. Weltens $N$, Zhao D, Van Oudenhove L. Where is the comfort in comfort foods? Mechanisms linking fat signaling, reward, and emotion. Neurogastroenterol Motil. 2014;26(3):303-15.

37. Ministério da Saúde (Brasil). Secretaria de Vigilância em Saúde. Vigitel Brasil 2013: vigilância de fatores de risco e proteção para doenças crônicas por inquérito telefônico. Brasília: Ministério da Saúde; 2014.

38. Zortea K, Bock PM, Moreno DB, Belmonte de Abreu PS. Anthropometric and biochemical assessment of schizophrenic patients taking clozapine. Rev Nutr. 2009;22(5):697-705. http://dx.doi.org/10.1590/\$14 15-52732009000500010

39. Levy RB, Claro RM, Monteiro CA. Sugar and total energy content of household food purchases in Brazil. Public Health Nutr. 2009;12(11):2084-91.

40. Monteiro CA, Levy RB, Claro RM, Ribeiro de Castro IR, Cannon G. A new classification of foods based on the extent and purpose of their processing. Cad Saúde Pública. 2010;26(11):2039-49.

41. Sachs GS, Guille C. Weight gain associated with use of psychotropic medications. J Clin Psychiatry. 1999;60 Supl 21:16-9. 
42. Allison DB, Casey DE. Antipsychotic-induced weight gain: A review of the literature. J Clin Psychiatry. 2001;62 Supl 7:22-31.

43. Meltzer HY, Perry E, Jayathilake K. Clozapineinduced weight gain predicts improvement in psychopathology. Schizophr Res. 2003;59(1):19-27.

44. Nihalani N, Schwartz TL, Siddiqui UA, Megna JL. Obesity and Psychotropics. CNS Neurosci Ther. 2012;18(1):57-63.

45. Melkersson KI, Dahl ML. Relationship between levels of insulin or triglycerides and serum concentrations of the atypical antipsychotics clozapine and olanzapine in patients on treatment with therapeutic doses. Psychopharmacology. 2003; 170(2):157-66.

46. Parsons B, Allison DB, Loebel A, Williams K, Giller E, Romano $S$, et al. Weight effects associated with antipsychotics: A comprehensive database analysis. Schizophr Res. 2009;110(1-3):103-10.

47. Citrome L, Holt RIG, Walker DJ, Hoffmann VP. Weight gain and changes in metabolic variables following olanzapine treatment in schizophrenia and bipolar disorder. Clin Drug Invest. 2011;31(7):455-82.

48. Leitão-Azevedo CL, Abreu MGB, Guimarães LR, Moreno D, Lobato MI, Gama CS, etal. Overweightand obesity in schizophrenic patients taking clozapine compared to the use of other antipsychotics. Rev Psiquiatr Rio Gd Sul. 2006;28(2):120-8.

49. Dickerson FB, Brown CH, Kreyenbuhl JA, Fang L, Goldberg RW, Wohheiter K, et al. Obesity among individuals with serious mental illness. Acta Psychiatr Scand. 2006;113(4):306-13.

50. Gurpegui M, Maria Martinez-Ortega J, GutierrezRojas L, Rivero J, Rojas C, Jurado D. Overweight and obesity in patients with bipolar disorder or schizophrenia compared with a non-psychiatric sample. Prog Neuropsychopharmacol Biol Psychiatry. 2012;37(1):169-75.

51. Fagiolini A, Frank E, Scott JA, Turkin S, Kupfer DJ. Metabolic syndrome in bipolar disorder: Findings from the Bipolar Disorder Center for Pennsylvanians. Bipolar Disord. 2005;7(5):424-30.

52. Almeida KM, de Macedo-Soares MB, Issler CK, Amaral JA, Caetano SC, Dias RDS, et al. Obesity and metabolic syndrome in Brazilian patients with bipolar disorder. Acta Neuropsychiatr. 2009;21(2):84-8.

53. Salvi VA, Albert U, Chiarle A, Soreca I, Bogetto F, Maina G. Metabolic syndrome in Italian patients with bipolar disorder. Gen Hosp Psychiat. 2008;30(4):318-23.

54. van Winkel $R$, De Hert $M$, Van Eyck $D$, Hanssens $L$, Wampers M, Scheen A, et al. Prevalence of diabetes and the metabolic syndrome in a sample of patients with bipolar disorder. Bipolar Disord. 2008;10(2):342-8.

55. Chang HH, Chou CH, Chen PS, Gean PW, Huang $\mathrm{HC}$, Lin CY, et al. High prevalence of metabolic disturbances in patients with bipolar disorder in Taiwan. J Affective Disord. 2009;117(1-2):124-9.

56. Salaroli LB, Barbosa GC, Mill JG, Molina MCB. Prevalence of metabolic syndrome in populationbased study, Vitoria, ES - Brazil. Arq Bras Endocrinol Metabol. 2007;51(7):1143-52.

57. Roick C, Fritz-Wieacker A, Matschinger $H$, Heider D, Schindler J, Riedel-Heller S, et al. Health habits of patients with schizophrenia. Soc Psychiatry Psychiatr Epidemiol. 2007;42(4):268-76.

58. Strassnig M, Brar JS, Ganguli R. Nutritional assessment of patients with schizophrenia: A preliminary study. Schizophr Bull. 2003;29(2):393-7.

59. Kilbourne AM, Rofey DL, McCarthy JF, Post EP, Welsh D, Blow FC. Nutrition and exercise behavior among patients with bipolar disorder. Bipolar Disord. 2007;9(5):443-52.

60. Bensenor IM, Brunoni AR, Pilan LA, Goulart AC, Busatto GF, Lotufo PA, et al. Cardiovascular risk factors in patients with first-episode psychosis in São Paulo, Brazil. Gen Hosp Psychiat. 2012;34(3):268-75.

61. Simonelli-Munoz AJ, Fortea MI, Salorio P, GallegoGomez JI, Sanchez-Bautista S, Balanza S. Dietary habits of patients with schizophrenia: A self-reported questionnaire survey. Int J Ment Health Nurs. 2012;21(3):220-8.

62. Amani R. Is dietary pattern of schizophrenia patients different from healthy subjects? BMC Psychiat. 2007;7:1-5. 